\title{
DEVELOPING AN INSTRUMENT FOR MEASURING THE FAITH OF THE STUDENTS OF ISLAMIC SENIOR HIGH SCHOOL
}

\author{
* ${ }^{1}$ Shodiq; ${ }^{2}$ Zamroni; ${ }^{3}$ Kumaidi \\ ${ }^{1}$ Faculty of Education and Teacher Training, Universitas islam Negeri Walisongo, Jl. Walisongo \\ No. 3-5, Tambakaji, Ngaliyan, Semarang Municipality, 50185, Central Java, Indonesia \\ ${ }^{2}$ Faculty of Economics, Universitas Negeri Yogyakarta, Jl. Colombo No. 1, Depok, Sleman, \\ 55281, Yogyakarta, Indonesia \\ ${ }^{3}$ Faculty of Psychology, Universitas Muhammadiyah Surakarta, Jl. A. Yani, Pabelan, Kartasura, \\ Surakarta, 57162, Central Java, Indonesia
}

\begin{abstract}
The study aims to develop an instrument used to measure faith of the students of Islamic senior high schools. The study was a research and development study consisting of three steps: pre development, development process, and presentation. The quantitative data analysis was to test the validity and reliability of the instrument and to test the model fit through the Confirmatory Factor Analysis (CFA) using LISREL 8.80 Program. The results of the study show that: (1) the faith instrument of the study is an inventory model of summated rating scale containing 113 items named as Islamic Faith Scale; (2) the instrument validity is considered as the loading factor value (the lowest loading factor value is 0.47 and the highest is 0.89 ). The instrument reliability regarded as the coefficient of the construct reliability is $>0.7$, (the coefficient of reliability construct of tashdiq al-qalb is 0.847 , and the coefficient of the construct reliability of amal al-qalb is 0.999); (3) the overall model fit produces a fit model indicated by Chi Square $(\chi 2)=48.23$, $\mathrm{df}=$ 64, $\mathrm{p}$-value $=0.929(\mathrm{p}>0.05)$, and Root Mean Square Error of Approximation $=0.000(<0.08)$.
\end{abstract}

Keywords: faith, scale, measurement, validity, reliability

\section{How to cite item:}

Shodiq, S., Zamroni, Z., \& Kumaidi, K. (2016). Developing an instrument for measuring the faith of the students of Islamic senior high school. Research and Evaluation in Education, 2(2), 181-193. doi:http://dx.doi.org/10.21831/reid.v2i2.11117

*Corresponding Author.

e-mail: shodiq.abdullah@yahoo.co.id 


\section{Introduction}

The goal of Islamic religion education instruction in schools and madrasabs is to build students' religiousity of Islamic teaching perspective in the perspective of Islamic teaching. Based on Islamic teaching perspective, religiosity is generally divided into three parts, namely (1) iman (belief, behavior and feeling); (2) ilmu (knowledge); (3) amal (behavior). The madrasab and school should implement those dimensions comprehensively and holistically.

The recent Islamic religion instruction is criticized for its inability to develop students' religiousness comprehensively and holistically. The instruction is oriented more toward developing the dimension of ilmu (knowledge and skill) than improving the dimension of iman and amal. For example, Azra (2002, p.178) states that the religion education approach prefers focusing on cognitive aspect to emphasizing affection aspect. Mas'ud (2002, p.212) states that 'the evaluation is just carried out by testing the cognitive aspect'.

Hadjar (2010, pp.216-218) asserts that the evaluation instrument on the affective domain is extremely limited. It leads to a problem of instrument development. For this reason, it is very important to develop an instrument for evaluating Islamic religion education learning related to the aspect of iman and amal for Islamic senior high school students. Therefore, the study aims to develop an instrument for measuring faith.

Researchers and experts have conducted empirical studies related to the development of instrumental faith issue. Hill and Hood (1999) review 126 instruments of psychological measurement on various aspects and religious perspectives; religious attitude, belief and religious practice, religious orientation, religious development, religious commitment, religious experience, value and religious moral, multidimension of religiosity, religious mysticism and spiritualism, the concept of God, death, eschatology, fundamentalism, etc.

Some researchers and experts have reported some research findings including Religious Belief Scale by Thouless in 1935 (Hill \& Hood, 1999, pp.10-11); Inventory of
Religious Belief by Brown and Lowe in 1951 (Hill \& Hood, 1999, pp.22-23); Religious Belief Scale by Martin and Nichols in 1962 (Hill \& Hood, 1999, pp.54-55); Religious Belief Inventory, a dissertation by R. R. Lee in Northwestern University, Illinois in 1965 (Hill \& Hood, 1999, pp.50-51); Santa Clara Strength of Religious Faith Questionnaire (SCSORF) which was developed by Plante and Boccaccini (1997); Spiritual Belief Inventory (SBI) developed by Holland, et al. (1998); an instrument development on religiosity measurement in the perspective of Islam Masri and Priester (2007), whose finding was the Religiosity of Islam Scale (RoIS), containing 19 items and two subscales: belief and religious practice.

Although Masri and Priester (2007) had the research on religiosity measurement, their theoretical construct and religiosity dimension were still in common sense. Therefore, the study is meant to develop an instrumental faith underlying the theoretical construct of faith in the Islamic theology perspective.

The word or term faith is most frequently encountered and discussed in the Qur'an. The Qur'an mentions the word 'faith' in various derivative forms no less than 550 times, such as: amanu, yu'minu, yu'minun, believers, and mu'minun. (Ensiklopedi Islam, 2002, p.208). Even according to Audah (2003, pp.77-81 and pp.787-789), the word 'faith' in its various forms found as many as 718 times in the Qur'an.

Etymologically, 'iman' is the belief of righteous deeds (Ilyas, 2007, p.17). In Islamic theology, iman is viewed in many perspectives. According to Murij'ah, the component of iman is the only ones, knowledge (ma'rifah). According to Mu'tazilah, iman is amal. According to Asy'ariyah, iman is tashdiq (belief) and Ibn Taymiyyah (nd) asserts that iman refers to amal al-qalb.

Ibn Taymiyyah (2003, p. 12-13) and Izutsu (1994, p.82) state that in semantics, the concept of iman refers to muthlaq sense (absolute, infinite), and muqayyad sense (finite and conditional). In the muthlaq sense, iman includes two principal dimensions: (a) the internal act dimensions or heart acts, and (b) the limbs act dimensions either verbally or action- 
ally (external act). In muqayyad sense, iman refers to internal act. This is in line with the meaning of Hadith by Ahmad from Anas that 'Islam is an external matter, whereas faith is the heart matter.'

Ibn Taymiyyah (2003, pp.12-13) and Izutsu (1994, pp.189-194) assert that iman does not cover tashdiq only. Tashdiq determines someone as muslim, but it does not guarantee to become mu'min unless it is accompanied with amal. The relationship between iman and amal is so close that they cannot be separated. Amal is a part of Iman.

As a part of iman refers to amal al-qalb (heart act), functioning as a sort of chain to relate between tashdiq (internal, absolute) and amal (external, active). Furthermore, Ibn Taymiyyah (2003, p. 12) explains the meaning of amal al-qalb in the concept of iman with the illustration as follows:

People commit adultery as they love the deed in their heart. They will never commit adultery if there is a real fear (khasyyah) to God, or there is a love to God (mababbah) in their heart so that they will refrain the desire.

Therefore, people who really love and believe in Allah, will never commit adultery. People commit adultery since they do not have (mahabbah) and (khasyyah) sense to Allah.

This is a kind of iman which is degradable from the buman's heart, although they will never loose the tashdiq. Hence, the people are called as muslim, but in case they are not mu'min.

Ibn Taymiyyah (2003, p.13) and Izutsu, (1994, p.195) emphasize that someone does not have all necessary condition in iman, although he has tashdiq, so he does not have iman basically. Tashdiq is just a part of iman. Tashdiq should have a mababbah and khasyyah to God. If Tashdiq leaves them, this will not be iman at all.

Basically, iman consists of two forms: (a) a deep belief in the form of tashdiq and actionable heart (amal al-qalb). A kind heart (salih) which is produced of iman, both belief and heart act, will produce a good external act. It is suitable with a kind iman in the heart (Ibn Taymiyya, al-Tubfah I, nd., p.172). The concept or theory of iman of Ibn Taymiyya is illustrated in Figure 1.

In this research, iman is defined as muqayyad sense. This is a condition and actionable heart or internal act which consists of tashdiq al-qalb and amal al-qalb. Tashdiq alqalb (belief) specifies a condition and actionable heart that straightens and believes in the doctrine of Islamic teachings (Din alIslam). Amal al-qalb (behavior or feeling and intention) specifies the condition and heart act that accepts situation and mental readiness to react or respond in appropriate ways. Therefore, the faith construct is developed from two dimensions: tashdiq al-qalb (belief), and amal al-qalb (behavior or feeling and intention).

As in Surah al-Baqarah (Al Qur'an: 2 verse 285) and Hadith narrated by Bukhari and Muslim (Al-Bukhari, nd.), Islamic faith concludes six articles: belief in Allah, His Angels, His Book, His Messenger, the Day of Judgment, and Qadla and Qadar. Meanwhile, according to Ibn Taymiyyah (nd:: 11, 289) faithful people are described as: syukur, khauf, mababbah,

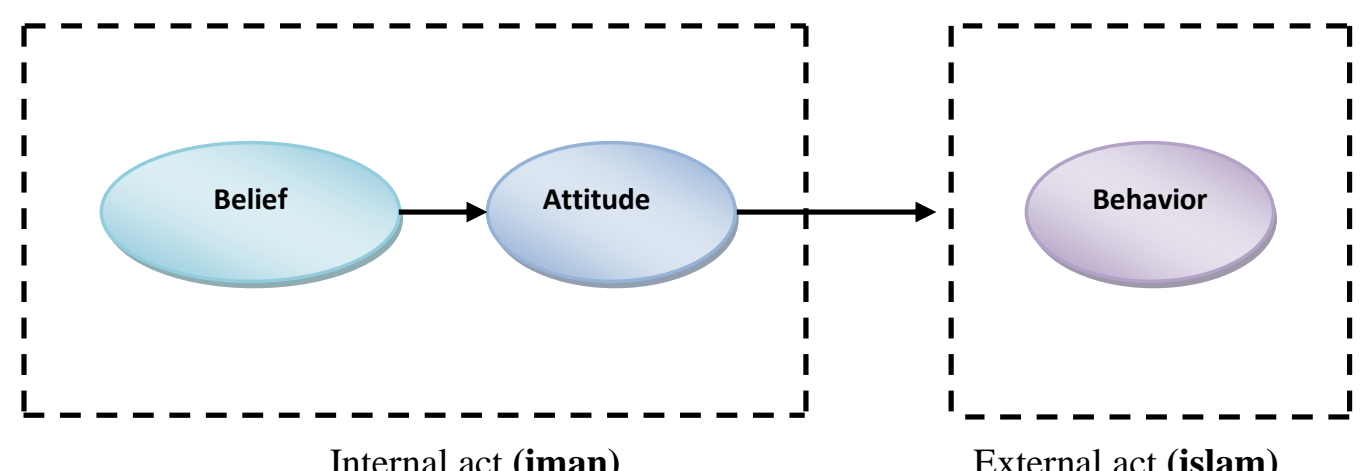

Figure 1. Relation among faith construct dimensions, and relation of iman and Islam 
shabar, tawakkal, raja, and ikblas. The measurement model and faith structure are illustrated in Figure 2.

Psychological faith engages three mental functionable components: cognition, affection, and conation. The mental functionable component is to believe in the religious doctrine and teachings of Islam (al-Din al-Islam). This function specifies iman which is closely related to tashdiq al-qalb. The functions of affection and conation refer to the feeling and mental state in facing reality and address problems in life with heart. This function specifies iman which is pertinent to amal alqalb.

In the case of psychological perspective, the faith (belief) should be higher than other domains such as desires, motives, attitudes, wishes, and needs. The belief causes personal one's goal in life (of the basis of their choice). The belief is considered as one's life principle, so that at a certain level, someone is better to sacrifice his/her life rather than to compromise his/her belief. Similarly, someone who has strong belief against the teachings or doctrine, he will do something as he believes, despite the obstacles impeding or whatever the risks. In fact, the faith is a part of private personality that could color a group or nation personality.

The belief is considered as abstract, but it is felt in oneself as the life principle and the drive of action. This belief that is considered as abstract that can be identified through one's conception and perception about life in relation to God and fellow being. The personal belief can also be radiated from the tendency of thinking, attitude and behavior patterns they perform. Someone who has a firm belief or aqidah Islamiyah will reveal good behavior or al-akblak al-karimah (noble character), in contrary to someone who has a weak and brittle belief or aqidah who tends to behave improperly in their daily lives.

The faith covers not only belief (tashdiq al-qalb), but also attitude and way of life (amal al-qalb). Behavior is the status of one's mental (Allen, Guy \& Edgley, 1980). It is a reaction against feeling (Azwar, 1995). It is also a readiness to react towards objects in certain ways (Bogardus 1931; Allport, 1935). The readiness is inclined to react in certain ways as an individual is faced with stimuli to respond (Azwar, 1995).

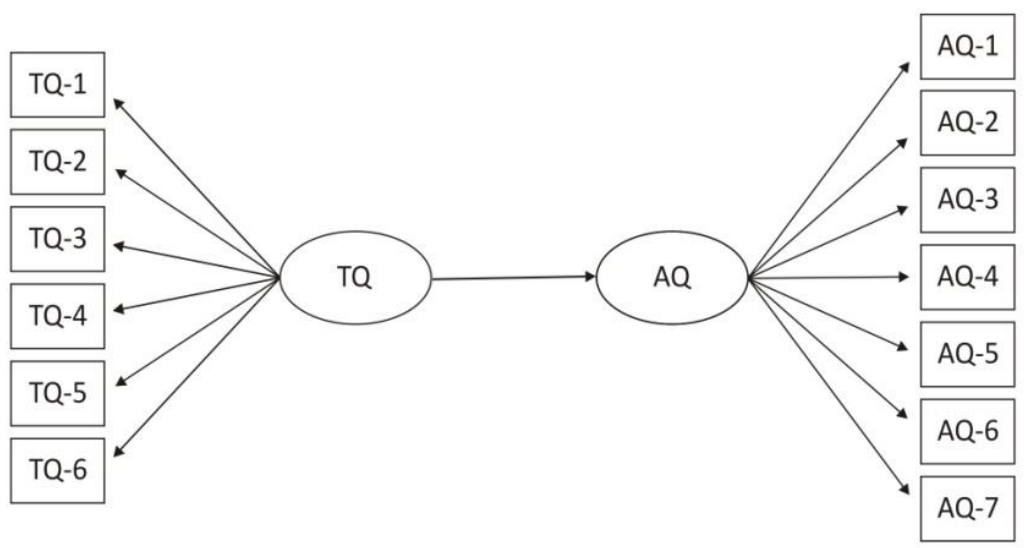

Figure 2. Measurement model and faith structure

Notes:

TQ : Dimension of Tashdiq al-Qalb (belief).

TQ1 : Belief in Allah.

TQ2 : Belief in His Angels.

TQ3 : Belief in His Messengers.

TQ4 : Belief in His Book.

TQ5 : Belief in the Day of Judgment.

TQ6 : Belief in Qadla and Qadar.
AQ : Dimension of Amal al-Qalb (Behavior and Feeling).

AQ1 : Thank God (Syukr).

AQ2 : Fear (Khauf).

AQ3 : Love (Mababbah).

AQ4 : Patience (Shabr).

AQ5 : Resignation (Tawakkal).

AQ6 : Hope (Raja').

AQ7 : Sincere (Ikhlash). 
Fishbein and Ajzen (1980) asserts that behavior is the function of belief and it specifies a condition that contributes to act and attitude. Hence, behavior is one of the factors affecting personalities. This behavior is called amal al-qalb. Ibn Taymiyyah states that this is a part of iman, because amal a-qalb (heart act) is a sort of chain to relate tashdiq (internal, absolute) and amal (external, active).

In the affection domain, experts developed techniques in order to reveal individual status in terms of an affection continuum. Hadjar (2010, p. 231) identifies some techniques that have been used in education. The expert used the techniques to measure individual status at an affection continuum. Those techniques include scale, questionnaire, observation, and interview. This research employed a scale technique. Scale is a technique of selfreport method using number of statements to which the participant responds. There are several different scales: Likert Scale, Thurstone Scale, Gutman Scale, Semantic Differential Scale. This research employs the likert model scale or summated rating scale. This scale is mostly used scale and it has a high reliability and correlation with the result of other scales as well (Shaw \& Wright, 1967, p. 15).

\section{Method}

This study is a research and development ( $R$ \& D) study. The research aimed to develop an instrumental product model included in 'summated rating scale', called faith scale and used to measure students' faith Islamic senior high school.

The research process was carried out through the stages of: (1) pre-development theoretical review on the faith concept in the perspective of Islamic theology; (2) development process consisting of: (a) arrangement of test specification and instrumental items, (b) the evaluation by Islamic religion expert and evaluation and measurement by psychometric expert; (c) quantitative analysis of tryout data; (3) presentation, rearrange the instruments after revision so that it is ready to use.

The construction of the items of the instrument involved three subject matter experts. The substantial aspect was evaluated by experts in Islamic studies. The instrumental establishment was done based on the experts' opinions in psychometrics and evaluation, and the language aspect was investigated by an Indonesian language expert. After the instrument has been revised, it would be simulated empirically. The research's participants were the students of Islamic senior high school grades XI and XII in Jepara Regency. The sample was established by using the purposive sampling method. The participants had to complete a minimally one year course.

The instrument was simulated in three steps: (1) the individual tryout was carried on 14 April 2013 and involved 18 students; (2) the small scale tryout or item discrimination test was administered on 6-12 May 2013, and involved 108 students. The item discrimination was tested with internal consistency using Pearson Product Moment Correlation. The internal consistency and reliability coefficient were calculated using SPSS 17.0 program; (3) the large scale tryout was carried out on 03-12 June 2013, and involved 439 students. The Confirmatory Factor Analysis (CFA) with LISREL 8.0 program is necessary to test the model fit of faith, validity, and reliability instrument. The model fit will be significant if it has minimum two criteria of three fit measurements: (1) Root Mean Square Error of Approximation (RMSEA) < 0.08; (2) Chi-Square (p) $>0.05$; and (3) Goodness of Fix Index $(\mathrm{GFI})>0.09$.

\section{Findings and Discussion}

\section{The Result of Expert Evaluation}

According to Ibn Taymiyyah, the construction of iman is divided into two dimensions: (1) belief (tashdiq al-qalb), and (2) behavior or feeling and intention (amal al-qalb). The dimension of belief tashdiq al-qalb consists of six aspects: belief in Allah, His Angels, His Book, His Messenger, the Day of Judgment, and Qadla and Qadar. Meanwhile, according to Ibn Taymiyyah (nd.: 11, 289) the dimension of amal al-qalb includes: syukur, khauf, mahabbah, shabar, tawakeal, raja', and ikblash.

The dimension of tashdiq al-qalb has six aspects that are developed into 25 indicators, and the dimension of behavior (amal al-qalb) 
includes in seven aspects which are developed into 25 indicators. This formula is evaluated and reviewed by experts in Islamic studies (Dirosah Islamiah). Based on the opinions of three experts in Islamic studies, some indicators need to be revised and eliminated. The result is that the faith construction reveals two dimensions: (1) the dimension of belief (tashdiq alqalb) which has 18 indicators covering six aspects, and (2) the dimension of behavior or feeling (amal al-qalb) includes in 17 indicators consisting of seven aspects.

The establishment of the faith instrument construction was based on supervisor, experts in psychometric, experts in educational evaluation, character education, and Indonesian language.

The evaluation and suggestion of the experts were used as the basic element to revise the items. Some of the instrument items are eliminated because they are unsuitable for the indicators, and developmental thinking and the soul of student's religiosity.

After reviewed based on the evaluation and suggestion from the expert, the faith scale had 120 items consisting of: 56 items of belief dimension (tashdiq al-qalb) and 64 items of behavior or feeling dimension (amal al-qalb).

\section{The Result of Item Descrimination Test}

The items will be eliminated if the correlation coefficient of item score and dimension total score is $<0.3$. The failed and eliminated items are: (a) items no. 4 and 8 on belief dimension; (b) items no. 13, 15, 21, 41 on behavior dimension. In the small group tryout, six items of the faith scale were eliminated. Therefore, the rest of items was 114 items. Then, the result of this tryout was ready to be tested in the large scale group by using the Confirmatory Factor Analysis ( $\mathrm{CF} A$ ) to test the faith measurement model.

\section{The Result of First dan Second Order CFA}

\section{The Dimension of Tashdiq al-Qalb}

The conceptual model and analysis result of belief dimension (tashdiq al-qalb) with CFA first order are indicated in Figure 3. The result of the analysis of the first order CFA as illustrated in Figure 3 shows that the model complies with the goodness of fit statistics. The model fit is indicated by Chi Square $(\chi 2)$ value $=152.52, \mathrm{df}=135, \mathrm{p}$-value $=0.144$, RMSEA $=0.058$. the $\mathrm{t}$ value is $>1.96$.

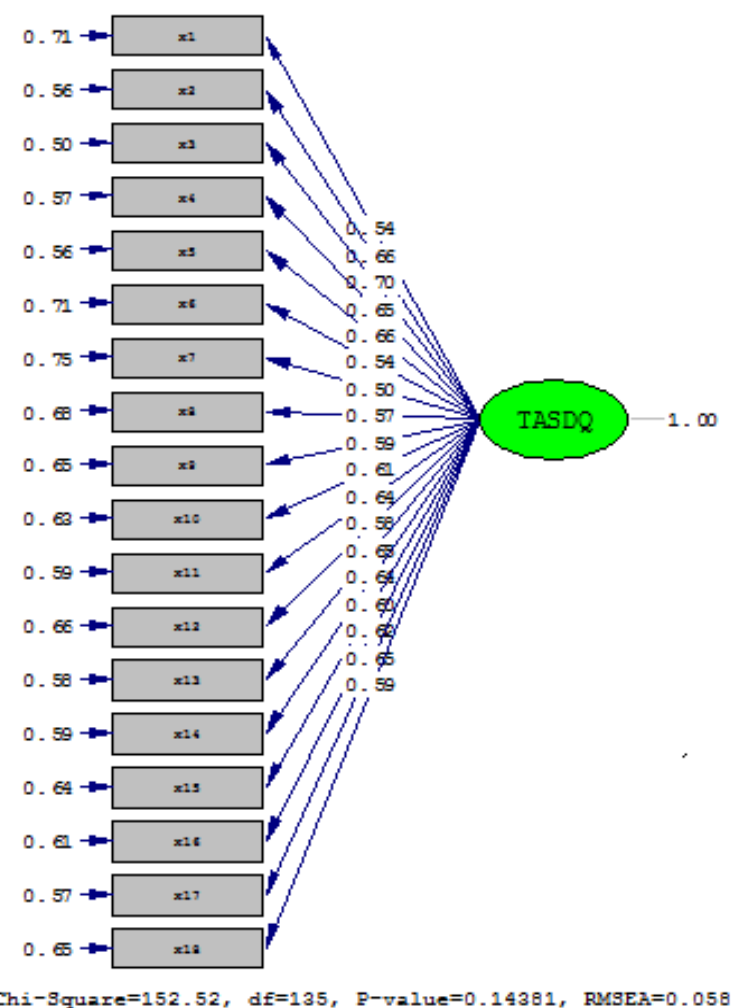

Figure 3. The result of $C F A$ First Order of Tashdiq al-Qalb dimension

Notes:

$\mathrm{X} 1$ : Belief in Allah to be The Only Creator

X2 : Belief in Allah to be the Only universal Creator and Organizer

X3 : Belief in Allah to be the great Giver of sustenance for His creature

X4 : Belief in Allah to be the only God to worship

X5 : Believe that Angels are servanst of God and Allah's messenger

X6 : Believe that Angels always obey Allah

X7 : Belief in Allah to be the only Source of holy book to His messenger

X8 : Belief in al-Qur'an to be the last book

X9 : Belief in the truth of teaching and guidance of alQur'an

X10 : Believe that Allah had sent His messengers

X11 : Believe that Muhammad is Allah's prophet and the last messenger

$\mathrm{X} 12$ : Believe that the messengers are very kind and ma'sum (infallible)

X13 : Believe that lives in the world would be ended

X14 : Belief in awakening (ba'ats)

$\mathrm{X} 15$ : Belief in final count (bisab)

$\mathrm{X} 16$ : Belief in heaven and hell

X17 : Believe that Allah has written the decree (predestination) for His creatures

X18 : Believe that everything happens in the world by His will 
Table 1 presents the CFA first order of the belief dimension.

Table 1. The result of First Order CFA of the dimension of Tashdiq al-Qalb

\begin{tabular}{ccccl}
\hline Indicator & $\begin{array}{c}\text { Loading } \\
\text { Factor }\end{array}$ & $\mathbf{t}-$ Value & $\mathbf{R}^{\mathbf{2}}$ & \multicolumn{1}{c}{ Note } \\
\hline $\mathrm{X} 1$ & 0.54 & 3.53 & 0.29 & Indicator Fit \\
$\mathrm{X} 2$ & 0.66 & 4.52 & 0.44 & Indicator Fit \\
$\mathrm{X} 3$ & 0.70 & 4.91 & 0.50 & Indicator Fit \\
$\mathrm{X} 4$ & 0.65 & 4.45 & 0.43 & Indicator Fit \\
$\mathrm{X} 5$ & 0.66 & 4.54 & 0.44 & Indicator Fit \\
$\mathrm{X} 6$ & 0.54 & 3.50 & 0.29 & Indicator Fit \\
$\mathrm{X} 7$ & 0.50 & 3.18 & 0.25 & Indicator Fit \\
$\mathrm{X} 8$ & 0.57 & 3.71 & 0.32 & Indicator Fit \\
$\mathrm{X} 9$ & 0.59 & 3.90 & 0.35 & Indicator Fit \\
$\mathrm{X} 10$ & 0.61 & 4.08 & 0.37 & Indicator Fit \\
$\mathrm{X} 11$ & 0.64 & 4.35 & 0.41 & Indicator Fit \\
$\mathrm{X} 12$ & 0.58 & 3.83 & 0.34 & Indicator Fit \\
$\mathrm{X} 13$ & 0.63 & 4.39 & 0.42 & Indicator Fit \\
$\mathrm{X} 14$ & 0.64 & 4.34 & 0.41 & Indicator Fit \\
$\mathrm{X} 15$ & 0.60 & 4.00 & 0.36 & Indicator Fit \\
$\mathrm{X} 16$ & 0.60 & 4.19 & 0.39 & Indicator Fit \\
$\mathrm{X} 17$ & 0.65 & 4.45 & 0.43 & Indicator Fit \\
$\mathrm{X} 18$ & 0.59 & 3.92 & 0.35 & Indicator Fit \\
\hline
\end{tabular}

The conceptual model and result of the second order CFA reveals the belief dimension (tashdiq al-qalb) as attached in Figure 4.

As shown in Figure 4, the model collaborates with the goodness of fit statistics. This is indicated by Chi Square $\left(\chi^{2}\right)$ value $=152.59$, $\mathrm{df}=129, \mathrm{p}$-value $=0.0765, \mathrm{RMSEA}=0.057$. The $t$ value is $>1.96$. Table 4 is the second order CFA fit indicator of belief dimension.

Table 2. The result of Second Order CFA of Tashdiq al-Qalb dimension

\begin{tabular}{ccccl}
\hline Indicator & $\begin{array}{c}\text { Loading } \\
\text { Factor }\end{array}$ & $\begin{array}{c}\mathbf{t}- \\
\text { Value }\end{array}$ & $\mathbf{R}^{\mathbf{2}}$ & \multicolumn{1}{c}{ Note } \\
\hline $\mathrm{X} 1$ & 0.58 & - & 0.33 & Reference V ar \\
$\mathrm{X} 2$ & 0.70 & 3.95 & 0.48 & Indicator Fit \\
$\mathrm{X} 3$ & 0.83 & 4.35 & 0.69 & Indicator Fit \\
$\mathrm{X} 4$ & 0.79 & 4.25 & 0.62 & Indicator Fit \\
$\mathrm{X} 5$ & 0.58 & - & 0.33 & Reference V ar \\
$\mathrm{X} 6$ & 0.50 & 3.63 & 0.25 & Indicator Fit \\
$\mathrm{X} 7$ & 0.52 & - & 0.27 & Reference Var \\
$\mathrm{X} 8$ & 0.59 & 3.28 & 0.35 & Indicator Fit \\
$\mathrm{X} 9$ & 0.60 & 3.32 & 0.36 & Indicator Fit \\
$\mathrm{X} 10$ & 0.62 & - & 0.38 & Reference Var \\
$\mathrm{X} 11$ & 0.76 & 4.30 & 0.58 & Indicator Fit \\
$\mathrm{X} 12$ & 0.72 & 4.15 & 0.52 & Indicator Fit \\
$\mathrm{X} 13$ & 0.75 & - & 0.56 & Reference Var \\
$\mathrm{X} 14$ & 0.74 & 5.27 & 0.55 & Indicator Fit \\
$\mathrm{X} 15$ & 0.63 & 4.44 & 0.39 & Indicator Fit \\
$\mathrm{X} 16$ & 0.57 & 4.05 & 0.33 & Indicator Fit \\
$\mathrm{X} 17$ & 0.88 & - & 0.78 & Reference V ar \\
X18 & 0.78 & 5.04 & 0.61 & Indicator Fit \\
\hline
\end{tabular}

Table 2 shows that all indicators are suitable for measuring the belief dimension. The 18 items are valid items in measuring the belief dimension (tashdiq al-qalb).

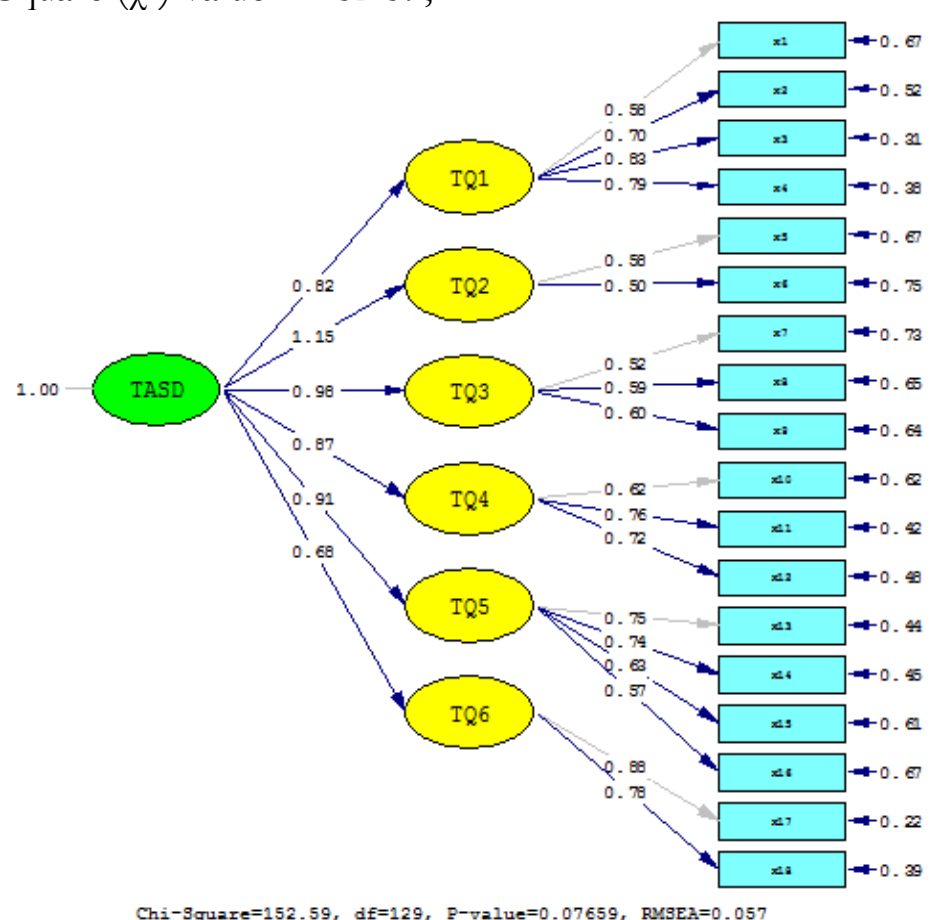

Chi-Square $=152.59, d f=129, \mathrm{P}-\mathrm{value}=0.07659, \mathrm{RMSEA}=0.057$

Figure 4. The result of CFA Second Order of Tashdiq al-Qalb dimension 


\section{The Dimension of Amal al-Qalb}

The conceptual model and the analysis result of the behavior dimension (amal al-qalb) using the first order $\mathrm{CFA}$ as indicated in Figure 5.

The analysis result of first order $C F A$ as illustrated in Figure 5 shows that the model collaborates with the goodness of fit statistics. The model fit is indicated by Chi Square $\left(\chi^{2}\right)$ value $=140.99, \mathrm{df}=119, \mathrm{p}$-value $=0.0824$, RMSEA $=0.066$. The $t$ on all indicators is $>$ 1.96. Table 3 is the fit indicator CFA first order of belief dimension.

Table 3 indicates that all indicators are suitable for measuring the belief dimension. The 17 indicators are valid to measure the behavior or feeling dimension (amal al-qalb).
Table 3. The Result of CFA First Order of Amal al-Qalb Dimension

\begin{tabular}{ccccc}
\hline Indicator & $\begin{array}{c}\text { Loading } \\
\text { Factor }\end{array}$ & $\mathbf{t}-$ Value & $\mathbf{R}^{\mathbf{2}}$ & Notes \\
\hline $\mathrm{X} 19$ & 0.63 & 4.43 & 0.40 & Indicator Fit \\
X20 & 0.55 & 3.74 & 0.31 & Indicator Fit \\
X21 & 0.51 & 3.43 & 0.26 & Indicator Fit \\
X22 & 0.56 & 3.77 & 0.31 & Indicator Fit \\
X23 & 0.63 & 4.36 & 0.39 & Indicator Fit \\
X24 & 0.65 & 4.54 & 0.42 & Indicator Fit \\
X25 & 0.67 & 4.76 & 0.45 & Indicator Fit \\
X26 & 0.60 & 4.15 & 0.36 & Indicator Fit \\
X27 & 0.57 & 3.92 & 0.33 & Indicator Fit \\
X28 & 0.61 & 4.20 & 0.37 & Indicator Fit \\
X29 & 0.64 & 4.52 & 0.42 & Indicator Fit \\
X30 & 0.60 & 4.12 & 0.36 & Indicator Fit \\
X31 & 0.66 & 4.61 & 0.43 & Indicator Fit \\
X32 & 0.68 & 4.57 & 0.42 & Indicator Fit \\
X33 & 0.53 & 3.56 & 0.28 & Indicator Fit \\
X34 & 0.65 & 4.53 & 0.42 & Indicator Fit \\
X35 & 0.66 & 4.70 & 0.44 & Indicator Fit \\
\hline
\end{tabular}

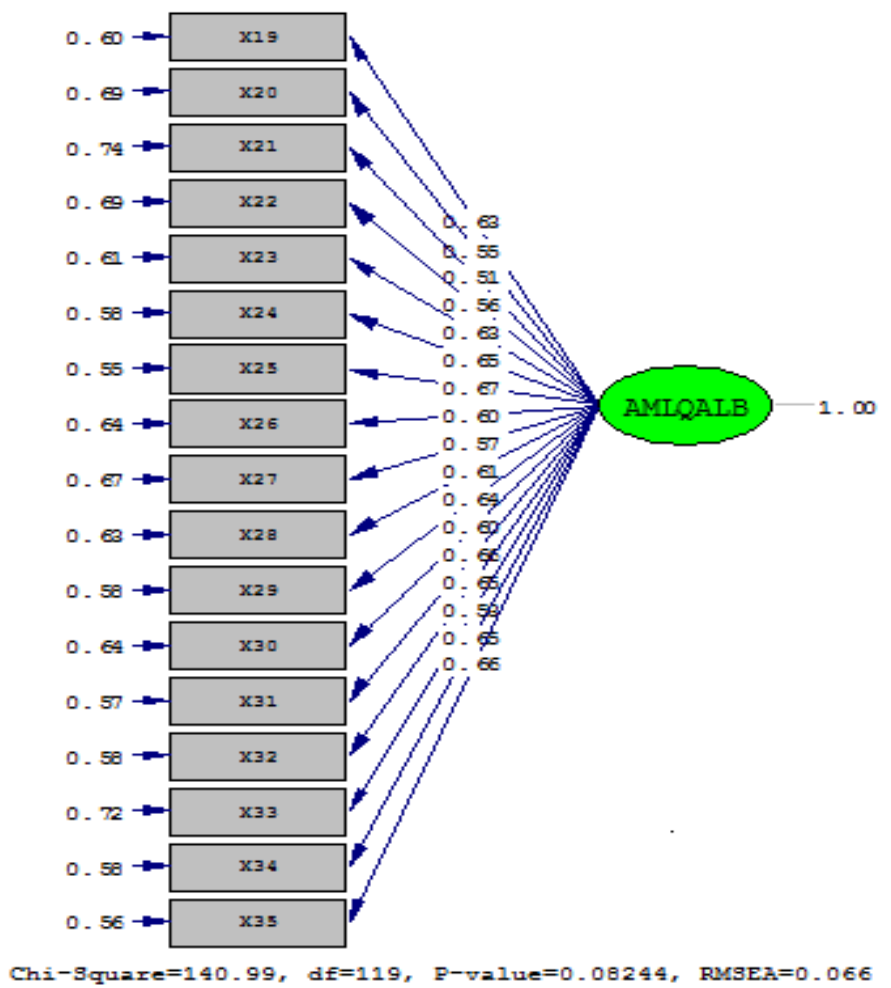

Figure 5. The result of CFA First Order of Amal al-Qalb dimension

Notes:

X19: Admit to all Allah's best creatures

$\mathrm{X} 20$ : Be positive to thinking

$\mathrm{X} 21$ : Being optimist

X22 : Feeling guilty about leaving Allah and His Messenger's order

X23 : Feeling guilty about breaking His prohibitation

X24 : Being afraid of Hell's threat

X25 : Feeling happy to do Allah and His messenger's order and leaving Allah and His messenger's prohibitation

X26 : Being tremble with sound of Allah's name
$\mathrm{X} 27$ : Being grateful for the tragedy and lackness

$\mathrm{X} 28$ : Being consistent with Allah and His messenger's order

X29 : Being consistent with Allah and His messenger's prohibitation

X30 : Being grateful for the result after efforting maximally

X31 : Recognizing human's limitation

$\mathrm{X} 32$ : Asking for His forgiveness

X33 : Hoping for His' mercy and heaven

X34 : Being honest only to Allah

X35 : Not to be hopeless at failure 
The conceptual model and analysis result of CFA Second Order of the behavior or feeling dimension (amal al-qalb) as indicated in Figure 6. In Figure 6, the model collaborates with the goodness of fit statistics.

Table 4. The result of Second Order CFA of Amal al-Qalb dimension

\begin{tabular}{ccccl}
\hline Indicator & $\begin{array}{c}\text { Loading } \\
\text { Factor }\end{array}$ & t-Value & $\mathbf{R}^{\mathbf{2}}$ & \multicolumn{1}{c}{ Notes } \\
\hline X19 & 0.62 & - & 0.38 & Reference V ar \\
X20 & 0.53 & 3.88 & 0.28 & Indicator Fit \\
X21 & 0.49 & 3.60 & 0.24 & Indicator Fit \\
X22 & 0.52 & - & 0.28 & Reference V ar \\
X23 & 0.74 & 3.75 & 0.55 & Indicator Fit \\
X24 & 0.73 & 3.72 & 0.53 & Indicator Fit \\
X25 & 0.89 & - & 0.79 & Reference V ar \\
X26 & 0.78 & 5.58 & 0.61 & Indicator Fit \\
X27 & 0.61 & - & 0.37 & Reference V ar \\
X28 & 0.64 & 4.09 & 0.41 & Indicator Fit \\
X29 & 0.68 & 4.30 & 0.47 & Indicator Fit \\
X30 & 0.75 & - & 0.57 & Reference V ar \\
X31 & 0.82 & 5.42 & 0.67 & Indicator Fit \\
X32 & 0.58 & - & 0.34 & Reference V ar \\
X33 & 0.47 & 3.73 & 0.22 & Indicator Fit \\
X34 & 0.71 & - & 0.51 & Reference V ar \\
X35 & 0.75 & 5.06 & 0.56 & Indicator Fit \\
\hline
\end{tabular}

The model fit is indicated by Chi Square $(\chi 2)$ value $=131.85, \mathrm{df}=112, \mathrm{p}$-value $=$
0.0969, RMSEA $=0.053$. The $\mathrm{t}$ of all indicators shows $>1.96$. Table 4 is the fit indicator of the second order CFA of the behavior or feeling and intention dimension. Table 4 indicates that all of the indicators are fit for measuring the behavior dimension. There are 17 items of valid indicators for measuring the behavior or feeling and intention dimension (tashdiq al-qalb).

\section{The Result of Measurement Model Testing}

The faith construct in the research is divided into two dimensions: tashdiq al-qalb (belief) and amal al-qalb (behavior and feeling). Referring to the theoretical review, as previously illustrated in Figure 1, the dimension of tashdiq al-qalb placed as exogen latent variable and the dimension of amal al-qalb as endogen latent variable. The latent variable of tashdiq al-qalb includes six aspects as an observed variable: belief in Allah, His Angels, His Books, His Messenger, the Day of Judgment, and Qadla and Qadar. Meanwhile, the dimension of amal al-qalb includes the following: syukur, khauf, mahabbah, shabar, tawakeal, raja', and ikblas.

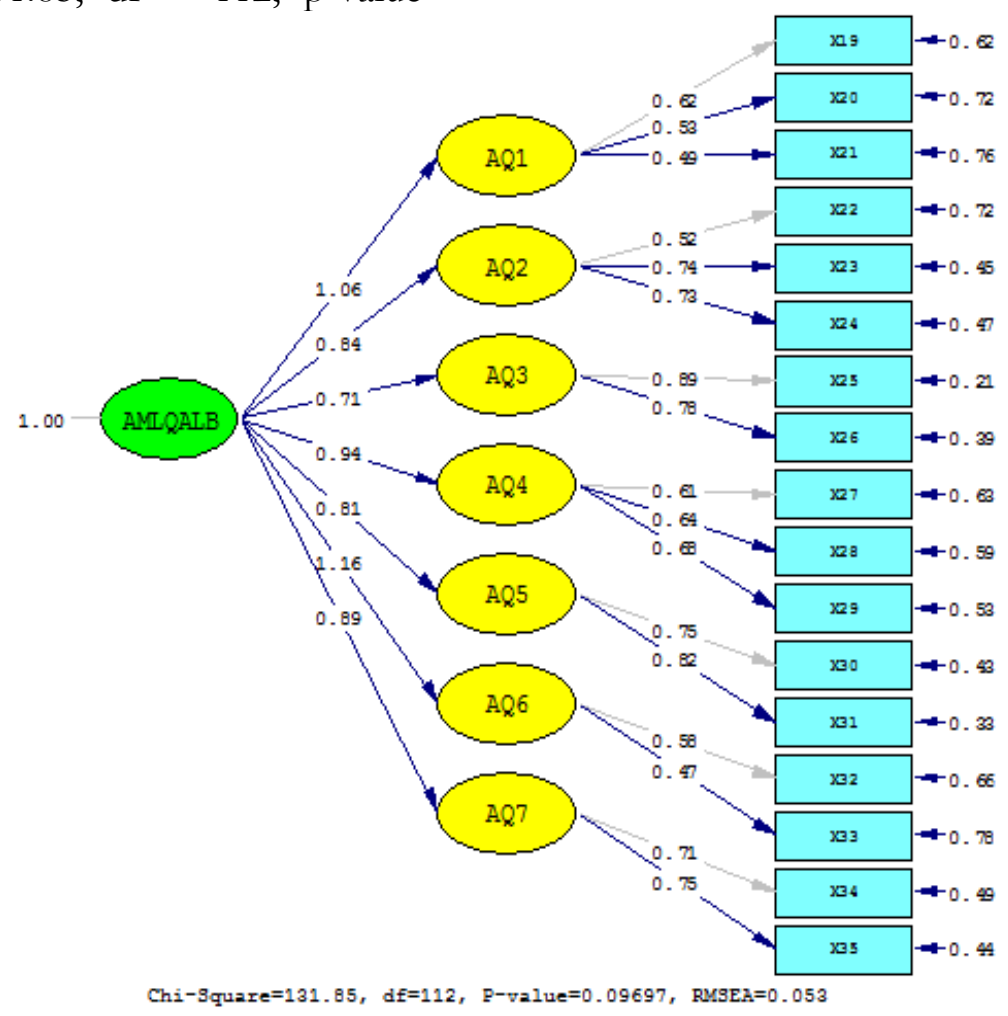

Figure 6. The result of First Order CFA of Amal al-Qalb dimension 
The conceptual model, the result of measurement model test, and faith structure are illustrated in Figure 7. Using Structural Equation Modelling (SEM), as presented in Figure7, the result of the analysis is: Chi Square $(\chi 2)=48.23, \mathrm{df}=64, \mathrm{P}$-value $=0.929$ $(\mathrm{p}>0.05)$, dan RMSEA $=0.000(<0.08)$. The result joins to the goodness of fit statistics so that the model is compatible with empirical data. The $t$ test of some parameter is significant $(t>1.96)$, as indicated in Figure 8. Using Structural Equation Modelling (SEM), the faith construct can be explained through some parameter elaborated as follows.

\section{Parameter of Lambda-X ( $\lambda)$}

The Parameter of Lambda-X $(\lambda)$ is the estimation of the loading factor of the observed variable. The parameter (tq1-tq6) is used to measure the exogenous latent vari- able. In this model, lambda-X shows the big role or contribution of the observed variables tq1 up to tq6. It is significant for measuring belief latent variabel (tashdiq al-qalb).

The result of the SEM analysis, as previously presented in Figure 2, shows that six observed variables (tq1- tq6) have the loading factor: 0.89 (tq1), 0.71 (tq2), 0.85 (tq3), 0.86 (tq4), 0.78 (tq5), and 0.75 (tq6). The $t$ value among six observed variables (tq1-tq6) are significant. Therefore, variabel tq1-tq6 is an appropriate variable to measure the belief latent variabel (tashdiq al-qalb).

In case of belief variable measurement (tashdiq al-qalb), the analysis result shows the observed variable tq1 (belief in Allah), tq4 (belief in His Messengers), and tq3 (belief in His Books) have a bigger value of loading factor or contribution than three observed variables.

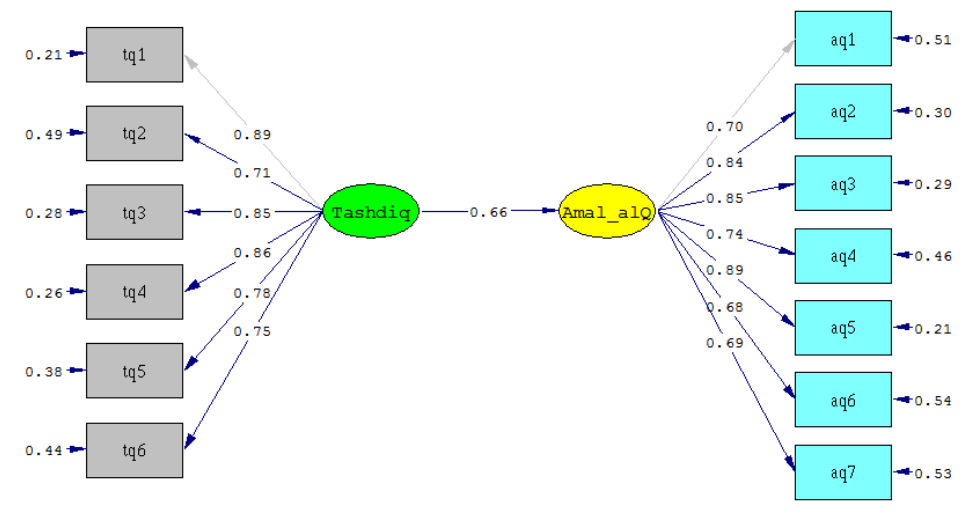

Chi-Square $=48.23, \mathrm{df}=64, \mathrm{P}-\mathrm{value}=0.92895, \mathrm{RMSEA}=0.000$

Figure 7. The result of faith measurement model test

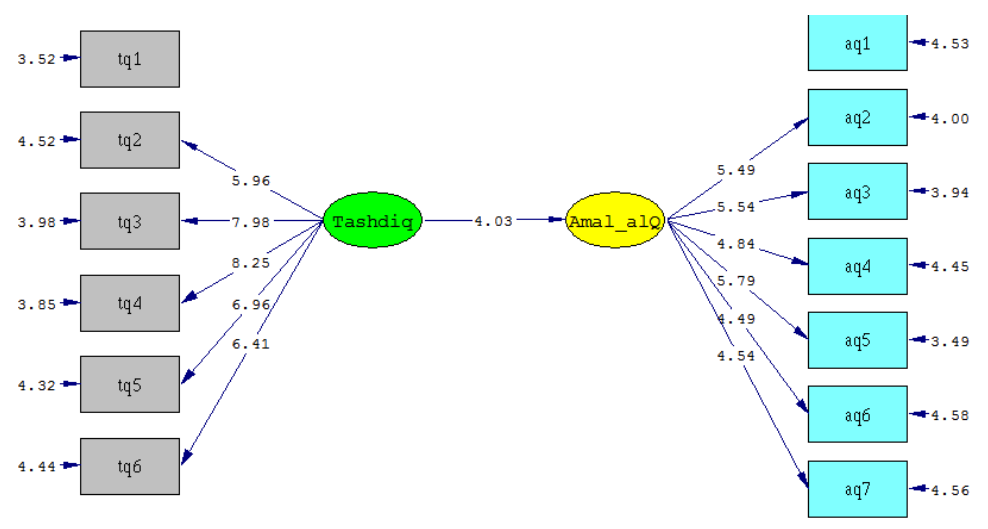

Chi-Square $=48.23, \mathrm{df}=64, \mathrm{P}-\mathrm{value}=0.92895, \mathrm{RMSEA}=0.000$

Figure 8 . The result of $t$ test model of faith measurement 
Parameter of Lambda-Y ( $\lambda)$

The Parameter of Lambda-Y $(\lambda)$ is the estimation of the loading factor on the observed variable $Y$ (aq1-aq7) to measure the endogenous latent variable. In this model, in case of belief or feeling latent variable measurement, lambda-Y shows the big role or contribution of observed variables aq1 until aq7.

The result of the SEM analysis in Figure 2 that is presented earlier shows that seven observed variables (aq1-aq7) have loading factors: 0.70 (aq1), 0.84 (aq2), 0.85 (aq3), 0.74 (aq4), 0.89 (aq5), 0.68 (aq6), and 0.69 (aq7). As added to Figure 3, the $t$ value of seven observed variables (aq1-aq7) are significant. Therefore, variables aq1 up to aq7 are appropriate variables for measuring behavior and feeling latent variable (amal al-qalb).

In the case of behavior variable measurement, the result of analysis reveals that the observed variable aq5 (Tawakkal), aq3 (Mababbah), and aq2 (Khauf) have a bigger loading factor or contribution than the other four observed variables.

\section{Parameter of Theta-Delta $(\delta)$}

The Parameter of Theta-Delta ( $\delta$ ) is the estimation of error measurement of observed variable X (tq1-tq6). As shown in Figure 2, error measurements of observed variable $\mathrm{X}$ (tq1- tq6) are: 0.21 (tq1), 0.49 (tq2), 0.28 (tq3), 0.26 (tq4), 0.38 (tq5), and 0.44 (tq6). The error measurement of observed variable tq2 (belief in Angels) is high because the variable of the loading factor is lower than that of the other loading factors of lambda-X.

\section{Parameter of Theta-Epsilon ( $\varepsilon$ )}

The Parameter of Theta-Epsilon $(\varepsilon)$ is the estimation of error measurement of observed variable $Y$ (aq1-aq7). As previously presented in Figure 2, the errors of measurement of observed variableY (aq1-aq7) are: 0.51 (aq1), 0.30 (aq2), 0.29 (aq3), 0.46 (aq4), 0.21 (aq5), 0.54 (aq6), and 0.53 (aq7). The error of measurement of observed variable aq6 (Raja') is high because the loading factor of the variable is lower than that of other loading factors of lambda-Y.
Parameter of Gamma ( $\gamma)$

The Parameter of Gamma $(\gamma)$ is the estimation of the direct effect of the exogenous latent variable (tashdiq al-qalb) on the endogenous latent variable (amal al-qalb). As shown in Figure 2, the estimation of Gamma $(\gamma)$ parameter is 0.66 as the direct effect belief (tashdiq al-qalb) to behavior or feeling (amal alqalb). The estimation significance of Gamma $(\gamma)$ parameter is $4.03(t>1.96)$, as described in Figure 3. Hence, the belief (tashdiq al-qalb) has a big role in or contribution to shaping and developing behavior and feeling (amal al-qalb) of someone.

In order to gain a fit model, the researchers used CFA to eliminate one item (an item of belief in the Day of Judgment). The rest of the total item is 113 tems: 53 items of belief dimension (tashdiq al-qalb), and 60 items of behavior and feeling dimension (amal alqalb).

The interpretation of the faith scale result data is understood using Theory of Reason Action. Fishbein and Ajzen (1975, p.16) state that the relation of attitude, intention, behavior, and belief is closely related and connected. According to the theory of reason action, one's attitude is determined by intention appearing because of one matter between two matters or two matters: (1) one's belief in a certain value in behaving to a certain attitude, or (2) the development of normative pressure in the society, named as subjective norm.

Belief and behavior (iman) is the internal behavior, while attitude (Islam) is the external behavior. Normatively, the relation of Islam and iman is closely related. The description of iman as the internal behavior and Islam as the external behavior is suitable with the statement of Ibn Taymiyyah (2003, p.13) quoted in a Hadith narrated by Ahmad from Anas that: 'Islam is an external matter, whereas faith is the heart/internal matter.'

\section{Conclusion}

The faith instrument of the study is an inventory or a self-report model of summated rating scale contained in 113 items named as Islamic faith scale and have two dimensions. 
The dimension of belief (tashdiq al-qalb) concludes 53 items describing student's belief in Allah, His Angels, His Books, His Messenger, the Day of Judgment, and Qadla and Qadar. The dimension of attitude (amal al-qalb) concludes 60 items describing attitude and personal feeling in self-condition, relation with God, and interaction with God.

The validity and reliability of the Islamic faith scale are considered as the high level. The instrument validity is considered as the loading factor value. The loading factor value of CFA first order of the dimension of Tashdiq alQalb is $0.50-0.70$, and the loading factor value of CFA second order of the dimension of Tashdiq al-Qalb is $0.50-0.88$. The loading factor value of CFA first order of the dimension of Amal al-Qalb is $0.51-0.68$, and the loading factor value of CFA second order of the dimension of Amal al-Qalb is from 0.47 (could be regarded as the lowest range) -0.89 (could be regarded as the highest range). The reliability construct of the instrument is considered as the coefficient of reliability construct is $>0.7$. The coefficient of the reliability construct of tashdiq al-qalb is 0.847 , and the reliability construct of amal al-qalb is 0.999 .

The overall model fit produces model fit as indicated by Chi Square $\left(\chi^{2}\right)=48.23$, df $=64, \mathrm{P}$-value $=0.929(\mathrm{p}>0.05)$, and the Root Mean Square Error of Approximation $($ RMSEA $)=0.000(<0.08)$. The result describes that the model fit is suitable to the data. The model is suitable for estimating population covariance matrix. The interpretation is not different from the sample covariance matrix so that the estimation result becomes a foundation of generalization. Wallahu A'lam.

\section{References}

Al-Bukhari, A. (tt.). Shabih al-bukhari, Juz I, Mesir: Dar Ihya al-Kutub.

Allen, D.E., Guy, F.F. \& Edgley, C.K. (1980). Social psychology as social process. Belmont, TN: Wadsworth.

Allport, G.W. (1935). Attitudes. In Murchison (ed.) Handbook of social psychology. Worcester, MA: Clark University Press.
Audah, A. (2003). Konkordansi qur'an: Panduan kata dalam mencari ayat Qur'an. Bogor: Pustaka Litera Antar Nusa.

Azra, A. (2002). Paradigma baru pendidikan nasional: Rekonstruksi dan demokratisasi. Jakarta: Kompas.

Azwar, S. (1995). Sikap manusia: Teori dan pengukurannya. Yogyakarta: Pustaka Pelajar.

Bogardus, E.S. (1931). Fundamentals of social psychology. New York, NY: Century.

Ensiklopedi Islam. (2002). Ensiklopedi Islam, Jilid 2. Jakarta: Ichtiar Baru Van Hoeve.

Fishbein, M. \& Ajzen, I. (1975). Belief, attitude, intention and behavior: An introduction to theory and research. London: Addison, Wesley.

Fishbein, M. \& Ajzen, I. (1980). Understanding attitude and predicting social behavior. New York, NY: Englewood Cliffs, Prentice Hall.

Hadjar, I. (2010). Evaluasi hasil belajar afektif pendidikan agama: Konsep dan pengukuran. In M. Muntholi'ah, A. Rahman, \& M.R. Chamami (Eds.), Guru besar bicara: Mengembangkan keilmuan pendidikan Islam. Semarang: RaSAIL.

Hill, P.C. \& Hood, R.W. (Eds.). (1999). Measures of religiosity. Birmingham: Religion education Press.

Holland, J.C., Kash, K.M., Passik, S., Gronert, M.K., Sison, A., Lederberg, M., ... Fox, B. (1998). A brief spiritual belief inventory for use in quality of life research in life-threatening illness. Psychooncology, 7(6), 460-469.

Ibn Taymiyyah, A. (nd.). Al-tubfah al-iraqiyah fi al-'amal al-qulub, Beirut: Dar al-Kutub al'Ilmiyah.

Ibn Taymiyyah, A. (nd.). Al-tubfah al-iraqiyah fi al-'amal al-qalbiyah, Riyadh: Maktabah alRusyd.

Ibn Taymiyyah, A. (2003). Kitab al-iman, Cairo: Dar al-Hadits. 
Ilyas, Y. (2007). Kuliah aqidah Islam. Yogyakarta: Lembaga Pengkajian dan Pengamalan Islam (LPPI) UMY.

Izutsu, T. (1994). The concept of belief in islamic theology: A semantical analysis of iman and islam. (A.F. Husein, et al., Trans.). Konsep kepercayaan dalam teologi islam: Analisis semantik iman dan islam. Yogyakarta: Tiara Wacana.

Mas'ud, A. (2002). Menggagas format pendidikan non dikotomik: Humanisme religius sebagai paradigma pendidikan Islam. Yogyakarta: Gama Media.
Masri, A.J. \& Priester, P.E. (2007). The development and validation of a Qur'an-based instrument to assess Islamic religiosity: The religiosity of Islam scale. Journal of Muslim Mental Health, 2, 177-188.

Plante, T.G. \& Boccaccini, M.T. (1997). The santa clara strength of religious faith questionnaire. Pastoral Psychology, 45, 5.

Shaw, M.E. \& Wright, J.W. (1967). Scales for the measurement of attitudes. New York, NY: McGraw Hill. 